\title{
Long-term imipramine treatment increases $N$-methyl-D-aspartate receptor activity and expression via epigenetic mechanisms
}

\section{Nguyen An Nghia ${ }^{a}$, Takae Hirasawa ${ }^{a, b^{*}}$, Hirotake Kasai ${ }^{\mathrm{c}}$, Chie Obata ${ }^{\mathrm{a}, \mathrm{b}}$, \\ Kohji Moriishi $^{\mathrm{c}}$, Kazuki Mochizuki ${ }^{\mathrm{d}}$, Schuichi Koizumi ${ }^{\mathrm{e}}$, and Takeo Kubota ${ }^{\mathrm{a}}$}

${ }^{\mathrm{a} D e p a r t m e n t}$ of Epigenetic Medicine, University of Yamanashi, 1110 Shimokato, Chuo, Yamanashi 409-3898, Japan

bJapan Science and Technology Agency (JST), CREST, 4-1-8 Honcho, Kawaguchi, Saitama, Japan

${ }^{\mathrm{c}}$ Department of Microbiology, University of Yamanashi, 1110 Shimokato, Chuo, Yamanashi 409-3898, Japan

${ }^{\mathrm{d}}$ Faculty of Life and Environmental Sciences, University of Yamanashi, Takeda, Kofu, Yamanashi 409-8510, Japan

${ }^{\mathrm{e}}$ Department of Pharmacology, University of Yamanashi, 1110 Shimokato, Chuo, Yamanashi 409-3898, Japan

*Corresponding author: Takae Hirasawa, Department of Epigenetic Medicine, University of Yamanashi, 1110 Shimokato, Chuo, Yamanashi 409-3898, Japan

Current address and contact details: 
Department of Biosciences, School of Science and Engineering, Teikyo University, 11 Toyosatodai, Utsunomiya, Tochigi 320-8551, Japan

Tel: +81 28-627-7212

Fax: +81 28-627-7187

E-mail: h-takae@ nasu.bio.teikyo-u.ac.jp 


\section{ABSTRACT}

Imipramine, a major antidepressant, is known to inhibit reuptake of serotonin and norepinephrine, which contributes to recovery from major depressive disorder. It has recently been reported that acute imipramine treatment inhibits $N$-methyl-D-aspartate (NMDA) receptor activity. However, the mechanisms underlying long-term effects of imipramine have not been identified. We tested these distinct effects in mouse cortical neurons and found that acute $(30 \mathrm{~s})$ imipramine treatment decreased $\mathrm{Ca}^{2+}$ influx through NMDA receptors, whereas long-term treatment $(48 \mathrm{~h})$ increased $\mathrm{Ca}^{2+}$ influx via the same receptors. Furthermore, long-term treatment increased NMDA receptor 2B (NR2B) subunit expression via epigenetic changes, including increased acetylation of histones $\mathrm{H} 3 \mathrm{~K} 9$ and $\mathrm{H} 3 \mathrm{~K} 27$ in the $N R 2 B$ promoter and decreased activity of histone deacetylase 3 (HDAC3) and HDAC4. These results suggest that the long-term effects of imipramine on NMDA receptors are quite different from its acute effects. Furthermore, increased NR2B expression via epigenetic alterations might be a part of the mechanism responsible for this long-term effect.

Keywords: imipramine, NMDA receptor, NR2B, neocortical neuron, epigenetics, histone acetylation 


\section{Introduction}

$\mathrm{N}$-Methyl-D-aspartate (NMDA) receptors are a family of ionotropic glutamate receptors, characterized by their voltage-dependent regulation of activity and high $\mathrm{Ca}^{2+}$ permeability. NMDA receptors form a heterotetramer from at least seven subunits (NR1, NR2A, NR2B, NR2C, NR2D, NR3A, and NR3B) (Flores-Soto et al., 2012; Loftis and Janowsky, 2003). These receptors are vital for brain function and central to many of the activity-dependent changes in synaptic strength and connectivity thought to underlie the formation of memory and learning (Hardingham and Bading, 2003). Recent studies have suggested that NMDA receptor dysregulation is associated with the pathogenesis of major depression (Beneyto et al., 2007; Pittenger et al., 2007). These include impairment of cortical neuroplasticity associated with NMDA receptor abnormalities (Cotter et al., 2002; Karpova et al., 2013; Nudmamud-Thanoi and Reynolds, 2004; Rajkowska et al., 1999), cognitive impairment due to chronic stress-induced alterations in NMDA receptor subunits (Yuen et al., 2012), and reduced expression of NR2A and NR2B subunits in the prefrontal cortex during major depression (Feyissa et al., 2009).

Imipramine, a tricyclic antidepressant, is known to aid recovery from a depressive state by inhibiting neuronal serotonin and norepinephrine transporters, leading to an elevation of extracellular monoamines (Haenisch and Bönisch, 2011), which is believed to relieve the 'catecholamine deficiency' seen in major depression (Schildkraut, 1965). Studies have reported that imipramine may also improve NMDA receptor regulation (Takebayashi et al., 2000). In fact, acute treatment with imipramine inhibits NMDA-induced increases in intracellular calcium $\left(\left[\mathrm{Ca}^{2+}\right]_{\mathrm{i}}\right)$ (Takebayashi et al., 2000). However, imipramine requires several weeks to exert its 
clinical effects, and the reason for this delay remains to be elucidated (Skolnick, 1999).

Acetylation of histone $\mathrm{H} 3$ (H3ac), a type of post-translational histone modification, can loosen DNA-histone interactions and enhance the transcription of target genes (Jenuwein and Allis, 2001; Kouzarides, 2007). Cellular histone acetylation is dynamic and maintained by histone deacetylases (HDACs) and acetyltransferases, classes of enzymes that remove acetyl groups from $\varepsilon$-N-acetyl lysine amino acids on a histone, or transfer acetyl groups from acetyl CoA to form $\varepsilon^{-}$ $\mathrm{N}$-acetyl lysine, respectively (De Ruijter et al., 2003). Recent studies have shown that HDAC regulation can play an important role in the pathophysiology of major depressive disorder as well as in the action of antidepressants, including imipramine (Tsankova et al., 2006; Tsankova et al., 2007; Krishnan and Nestler, 2008).

In the present study, we investigated the mechanism underlying imipramine's long-term effect via NMDA receptor with the hypothesis that epigenetic regulation might be associated with these effects.

\section{Materials and Methods}

\subsection{Primary neocortical cell cultures}

Primary cultures of neocortical neurons were prepared from ICR (CD-1) mouse fetuses on embryonic day 15 . Briefly, neocortices were carefully dissected, minced, and digested with $0.25 \%$ trypsin in the presence of $0.5 \mathrm{mg} / \mathrm{ml}$ DNAase I. Isolated cells were suspended in Neurobasal media (Life Technologies Ltd, Carlsbad, CA) supplemented with 1\% L-glutamine, penicillin/streptomycin, and B27 serum-free supplement (Life Technologies Ltd), and plated at a density of $10^{5}$ cells $/ \mathrm{cm}^{2}$ in polyethylenimine (PEI)-coated cover glasses or PEI-coated plastic dishes. These 
cultures were maintained at $37^{\circ} \mathrm{C}$ in humidified $5 \% \mathrm{CO}_{2}$. Experimental protocols were approved by the Institute Animal Care and Use Committee of the University of Yamanashi.

\subsection{Drugs and treatments}

The chemicals were supplied as follows: NMDA (Tocris Bioscience, Bristol, UK); dizocilpine (MK-801; Tocris Bioscience); 6-cyano-7-nitroquinoxaline-2,3-dione (CNQX; Sigma-Aldrich); tetrodotoxin (TTX; Wako Pure Chemical Industries, Osaka, Japan); trichostatin A (TSA; Cyclex Ltd, Nagano, Japan); and imipramine (SigmaAldrich). All compounds were dissolved in distilled water.

Cultured cells were used to evaluate acute and long-term effects of imipramine. To measure acute effects, cultured cells at day 5 in vitro (DIV5) were exposed to 10 $\mu \mathrm{M}$ NMDA and to consecutive applications of $0,1,3,10$, or $30 \mu \mathrm{M}$ imipramine for $30 \mathrm{~s}$. Between applications, cells were washed for 5 min with balanced salt solution (BSS). To evaluate the long-term effects of imipramine, cultured neurons at DIV3 were assigned to one of two treatment conditions: vehicle control (distilled water) or imipramine treatment $(0.5,1,3,5$, or $10 \mu \mathrm{M})$. These cultures were harvested after 48 h, on DIV5.

\subsection{Calcium imaging}

Calcium imaging was performed as previously described (Hirasawa et al., 2000). Briefly, neocortical neurons were loaded with $7.5 \mu \mathrm{M}$ Fura-2/AM (Dojindo Laboratories, Kumamoto, Japan) for $30 \mathrm{~min}$ at $37^{\circ} \mathrm{C}$ in $\mathrm{BSS}(\mathrm{NaCl}, 130 \mathrm{mM} ; \mathrm{KCl}, 5.4$ $\mathrm{mM}$; glucose, $5.5 \mathrm{mM}$; HEPES, $20 \mathrm{mM} ; \mathrm{CaCl}_{2}, 2 \mathrm{mM}$; adjusted to $\mathrm{pH}$ of 7.4 with $\mathrm{NaOH})$. After three washes with BSS, cells were mounted on the stage of an inverted 
fluorescent microscope (TE-200V, Nikon Corporation, Tokyo, Japan), and perfused with BSS at $2 \mathrm{~mL} / \mathrm{min}$. Fluorescent images were obtained by alternating excitation with $340 \mathrm{~nm}$ and $380 \mathrm{~nm}$ light, viewed through a 20X objective lens and recorded using a CCD video camera (ORCA-R ${ }^{2}$, Hamamatsu Photonics K.K., Hamamatsu, Japan). Images were simultaneously digitized, integrated, and converted into 340/380 $\mathrm{nm}$ ratio images using an image processor (AQUACOSMOS, Hamamatsu Photonics K.K.) for subsequent two-dimensional ratiometric analysis. In all cases, calcium recordings were obtained from somatic regions.

\subsection{Determination of cell survival}

Neuronal survival following long-term imipramine treatment was determined with MTT assays. Briefly, neocortical neurons were seeded $\left(10^{5}\right.$ cells $\left./ \mathrm{cm}^{2}\right)$ in a $96-$ well plate. After $48 \mathrm{~h}$ of imipramine treatment at DIV5, the old medium was discarded, and $100 \mu \mathrm{l}$ of MTT solution $(0.25 \mu \mathrm{g} / \mu \mathrm{l}$ in neurobasal medium; Dojindo, Japan) was added to each well. After $2 \mathrm{~h}$ of incubation at $37^{\circ} \mathrm{C}, 100 \mu \mathrm{MTT}$ stop solution (20\% SDS, 50\% dimethylformamide in distilled water) was added, the 96well plate was placed on a rocking mixer for $3 \mathrm{~h}$ at room temperature. The absorbance value of each well was measured at $570 \mathrm{~nm}$.

\subsection{Western blotting}

Primary cultures of neocortical neurons were harvested and suspended in phosphate-buffered saline containing $137 \mathrm{mM} \mathrm{NaCl}, 2.7 \mathrm{mM} \mathrm{KCl}, 8.1 \mathrm{mM} \mathrm{Na}{ }_{2} \mathrm{HPO}_{4}$, and $1.47 \mathrm{mM} \mathrm{KH}_{2} \mathrm{PO}_{4}\left(\mathrm{pH} \mathrm{7.35-7.65)}\right.$ and centrifuged at $20400 \mathrm{~g}$ for $5 \mathrm{~min}$ at $4^{\circ} \mathrm{C}$. Pellets were collected and resuspended in lysis buffer containing $50 \mathrm{mM}$ Tris, $25 \mathrm{mM}$ $\mathrm{KCl}, 5 \mathrm{mM} \mathrm{MgCl} 2,250 \mathrm{mM}$ sucrose, $5 \%$ triton-100, and protease inhibitor cocktail 
(Nacalai Tesque, Kyoto, Japan). Histones from cultured cells were extracted according to a procedure described by Yoshida (Yoshida et al., 1990). Depending on the experiment, $10 \mu \mathrm{g}$ protein or nuclear extract was run using sodium dodecyl sulphate polyacrylamide gel electrophoresis (SDS-PAGE) and subsequently blotted on polyvinylidene fluoride membranes (EMD Millipore, Billerica, MA, USA). After blocking for $1 \mathrm{~h}$, membranes were incubated overnight at $4{ }^{\circ} \mathrm{C}$ with one of the following primary antibodies: mouse anti-NR1 (1:1000; Millipore, Temecula, CA); rabbit anti-NR2B (1:1000; Millipore); rabbit anti-NR2A (1:1000; Millipore); rabbit anti-mGluR5 (1:1000; Millipore); rabbit anti-acetyl-histone H3K9 (1:1000; Cell Signaling Technology, MA, USA); rabbit anti-acetyl-histone H3K27 (1:1000; Cell Signaling Technology); rabbit anti-histone H3 (1:1000; Cell Signaling Technology); rabbit anti-HDAC1, HDAC2, HDAC3, HDAC4, and HDAC5 (1:1000; Cell Signaling Technology), rabbit anti-HDAC 11 (1:1000; Millipore); or mouse anti- $\beta$-actin (1:1000; Cell Signaling Technology). Membranes were washed three times and then incubated with appropriate secondary horseradish peroxidase-linked antibodies. Immunoreactivity was visualized with a standard chemiluminescence detection system (ECL; Nacalai Tesque Inc.) and imaging analysis software (LAS-4000, Fujifilm Inc., Tokyo, Japan). Intensities were normalized as a ratio relative to $\beta$-actin or histone $\mathrm{H} 3$.

\subsection{Measurement of HDAC inhibition}

Nuclear extracts from cultured neocortical neurons were prepared using a Nuclear Extract Kit (Active Motif, CA, USA). HDAC inhibition was examined using an HDAC Assay Kit (Epigentek Group Inc. NY, USA) according to the manufacturer's instructions. Briefly, $5 \mu \mathrm{g}$ of nuclear extracts from untreated control or 
imipramine-treated neurons were incubated with acetylated histone $\mathrm{H} 3 \mathrm{for} 45 \mathrm{~min}$ at room temperature. The remaining un-deacetylated substrate was measured using a fluorescent plate reader, and the percentage of HDAC inhibition was calculated according to the manufacturer's formula.

\subsection{Chromatin immunoprecipitation}

Chromatin immunoprecipitation (ChIP) was performed following a modified published protocol (Honma et al., 2013). Primary cultured neocortical neurons (in $60.1 \mathrm{~cm}^{2}$ dishes) were cross-linked with $1 \%$ formaldehyde for $30 \mathrm{~min}$ at room temperature $\left(\sim 25^{\circ} \mathrm{C}\right)$. Fixation was stopped with the addition of glycine. Cells were collected and washed with cold phosphate-buffered saline containing $2 \%$ foetal bovine serum and $0.05 \% \mathrm{NaN}_{3}$. Cell pellets were resuspended in SDS lysis buffer and kept on ice for $2 \mathrm{~h}$. Samples were sonicated on ice to break chromatin DNA to an average length of 200-500 base pairs (bp). Supernatants were centrifuged at 3,000 $\mathrm{rpm}$ for $1 \mathrm{~min}$ then pre-cleared with protein $\mathrm{G}$ beads at $4{ }^{\circ} \mathrm{C}$ to reduce non-specific background. Pre-cleared chromatin was incubated with $0.5 \mu \mathrm{g}$ of rabbit anti-acetylhistone $\mathrm{H} 3 \mathrm{~K} 9$, anti-acetyl-histone $\mathrm{H} 3 \mathrm{~K} 27$, and $1 \mu \mathrm{g} \mathrm{IgG} \mathrm{(negative} \mathrm{control)} \mathrm{and}$ rotated at $4{ }^{\circ} \mathrm{C}$ for $12-16 \mathrm{~h}$. Immunoprecipitation was carried out with protein $\mathrm{G}$ beads. Beads were sequentially washed and immune complexes eluted using ChIP direct elution buffer $(0.5 \%$ SDS, $5 \mathrm{mM}$ ethylenediaminetetraacetic acid, $10 \mathrm{mM}$ Tris- $\mathrm{HCl}$, $0.3 \mathrm{M} \mathrm{NaCl})$. Cross-links were reversed by heating at $65^{\circ} \mathrm{C}$ overnight. After treatment with proteinase $\mathrm{K}$ for $1 \mathrm{~h}$ at $55^{\circ} \mathrm{C}$, DNA was purified by phenol-chloroform extraction and ethanol precipitation. Gene expression was measured using quantitative reverse transcription polymerase chain reaction (qRT-PCR) using an ABI Prism 7500 (Applied Biosystems) and SYBR Green PCR kit (SYBR Green ER, Life Technologies 
Ltd). PCR amplification was conducted over 40 cycles, using primer pairs specific for $200 \mathrm{bp}$ segments corresponding to the upstream region of the mouse $N R 2 B$ gene (Qiang et al., 2010). Primer sequences are described in Table S1.

\subsection{Statistical analysis}

All values are expressed as mean \pm standard error of the mean for $n$ independent observations. Comparisons of multiple groups were performed with one-way analysis of variance (ANOVA), followed by Tukey's post hoc test or Dunnett's T3 test. Differences were considered significant when $\mathrm{P}$ values were less than 0.05 .

\section{Results}

3.1. Effect of acute imipramine treatment on $\mathrm{Ca}^{2+}$ influx through NMDA receptors in primary cultured neocortical neurons

To evaluate the effects of acute imipramine on $\mathrm{Ca}^{2+}$ influx, we measured $\mathrm{Ca}^{2+}$ response in neocortical neurons. After 30-min loading with calcium indicator Fura2/AM, primary cultured neocortical neurons at DIV5 were washed three times with BSS. Subsequently, these neurons were subjected to consecutive 30-s treatments of 10 $\mu \mathrm{M}$ NMDA in the presence of $0,1,3,10$, and $30 \mu \mathrm{M}$ imipramine (Fig. 1A). We used a non-competitive NMDA receptor antagonist, MK-801 (5 $\mu \mathrm{M})$, to confirm the effects of NMDA on $\mathrm{Ca}^{2+}$ influx. As a result, we showed that imipramine inhibited NMDAinduced $\mathrm{Ca}^{2+}$ influx (NMDA response) in a concentration-dependent manner (Fig. 1A). The half-maximal inhibitory concentration of imipramine $\left(\mathrm{IC}_{50}\right)$ for the NMDA response was $30 \mu \mathrm{M}$, which had an effect similar to that of $5 \mu \mathrm{M}$ MK-801 (Fig. 1B). This NMDA response was recovered by washing out imipramine with BSS. These results suggest that acute imipramine treatment inhibits NMDA-induced $\mathrm{Ca}^{2+}$ influx in 
neocortical neurons. To determine appropriate concentrations of long-term imipramine treatment, we first evaluated the effect of long-term imipramine treatment on neuronal viability using MTT assays. Primary cultured neocortical neurons at DIV3 were treated with $1,3,5,10$, and $30 \mu \mathrm{M}$ of imipramine for $48 \mathrm{~h}$. We found that $30 \mu \mathrm{M}$ imipramine significantly reduced neuronal survival, while the other concentrations $(1,3,5$, or $10 \mu \mathrm{M})$ did not change viability of neurons (Fig. S1).

\subsection{Effect of long-term imipramine treatment on $\mathrm{Ca}^{2+}$ influx through NMDA receptors} in primary cultured neocortical neurons

To investigate the long-term effects of imipramine on NMDA-induced $\mathrm{Ca}^{2+}$ influx, we examined NMDA response in primary cultured neocortical neurons at DIV5 treated with 1,3 , or $10 \mu \mathrm{M}$ of imipramine for $48 \mathrm{~h}$. We found that $\mathrm{Ca}^{2+}$ influx increased in a dose-dependent manner with long-term imipramine treatment (Fig. 2A, B). This effect was in direct contrast to the decrease in $\mathrm{Ca}^{2+}$ influx that was seen following acute imipramine treatment.

NMDA-induced $\mathrm{Ca}^{2+}$ influx can be mediated not only by NMDA receptors, but also by voltage-gated calcium channels, which are controlled by voltage-gated sodium channels and by $\alpha$-amino-3-hydroxy-5-methyl-4-isoxazolepropionic acid (AMPA) receptors (Miyakawa et al., 1992; Joshi et al., 2011). Therefore, we examined NMDA response following treatment with TTX, a voltage-gated sodium channel blocker, and CNQX, a competitive AMPA receptor antagonist. We observed a similar concentration-dependent increase in NMDA response (Fig. 2C). These results suggest that long-term imipramine enhances NMDA-induced $\mathrm{Ca}^{2+}$ influx in primary cultured neocortical neurons. 


\subsection{Expression of NMDA receptors following long-term imipramine treatment}

Based on our finding that long-term imipramine increases NMDA-induced $\mathrm{Ca}^{2+}$ influx in neocortical neurons, we hypothesized that imipramine would enhance NMDA receptor activity by increasing NMDA receptor expression. Thus, we measured expression of NMDA receptor subunits, including NR1, which is widely expressed in the whole brain (Takai et al., 2003), and NR2A and NR2B, which are expressed in cerebral cortex of the developing brain (Li and Tsien, 2009; Loftis and Janowsky, 2003). NR1, NR2A, and NR2B were measured in primary cultures of neocortical neurons at DIV5 following $48 \mathrm{~h}$ imipramine treatment. There was no corresponding increase in NR1 or NR2A expression (Fig. 3A, B); however, long-term treatment with imipramine significantly increased expression of NR2B protein (Fig. 3C). These results suggest that increased expression of the NMDA receptor subunit NR2B may be involved in the enhancement of NMDA receptor activity.

Since recent reports have also suggested that metabotropic glutamate receptor 5 (mGluR5) receptors are functionally connected with NMDA receptors (Attucci et al., 2001; Awad et al., 2000; Nowak et al., 2014), we next investigated whether long-term imipramine treatment affects mGluR5 expression in neocortical neurons. The results did not show any significant change in mGluR5 expression following long-term imipramine treatment (Fig. S2).

\subsection{Global epigenetic changes induced by long-term imipramine treatment}

Given that long-term imipramine treatment altered NR2B expression, we hypothesized that the alteration may be caused by epigenetic histone modifications. Therefore, we investigated activity and expression of HDACs following long-term treatment with imipramine $(0.5,1,3,5$, or $10 \mu \mathrm{M})$. Trichostatin A, a well-known 
HDAC inhibitor (Furumai et al., 2001; Yoshida et al., 1995), was used as positive control. We found that long-term treatment with imipramine decreased HDAC activity in a concentration-dependent manner (Fig. 4A).

In order to determine which HDACs were affected by imipramine, we investigated expression of six HDACs (HDAC1, HDAC2, HDAC3, HDAC4, HDAC5, and HDAC11), each of which are highly expressed in the cortex (Broide et al., 2007). We observed a significant decrease in HDAC3 (class I) and HDAC4 (class II) expression following imipramine and no significant decreases in the other HDACs (Fig. 4B).

\subsection{Long-term imipramine treatment increases global histone H3 acetylation}

As long-term imipramine decreased global HDAC activity, and HDAC3 and HDAC4 expression, we hypothesized that long-term imipramine increases histone acetylation. To test this hypothesis, we examined levels of histone $\mathrm{H} 3$ acetylation at $\mathrm{K} 9(\mathrm{H} 3 \mathrm{~K} 9 \mathrm{ac})$ and $\mathrm{K} 27(\mathrm{H} 3 \mathrm{~K} 27 \mathrm{ac})$. We found that imipramine increased H3K9ac in a concentration-dependent manner, with significant increases following $5 \mu \mathrm{M}(\mathrm{n}=9, \mathrm{P}$ $<0.05)$ and $10 \mu \mathrm{M}$ imipramine $(\mathrm{n}=9, \mathrm{P}<0.05$, Fig. 5A) treatment. Similarly, imipramine increased $\mathrm{H} 3 \mathrm{~K} 27 \mathrm{ac}$ in a concentration-dependent manner, with significant increases after $5 \mu \mathrm{M}(\mathrm{n}=6, \mathrm{P}<0.05)$ and $10 \mu \mathrm{M}$ imipramine $(\mathrm{n}=6, \mathrm{P}<0.05$, Fig. 5B) treatment. These results indicate that long-term treatment with imipramine increases gene expression.

\subsection{Long-term effect of imipramine on local histone acetylation of the NR2B}

promoter 
The upregulation of NR2B and increased global histone acetylation induced by long-term treatment with imipramine suggests that histone acetylation in the upstream region of $N R 2 B$ may be altered. Thus, we investigated histone $\mathrm{H} 3$ acetylation in this region using a ChIP assay, with 10 primer sets encompassing the 5'-regulatory region of $N R 2 B$ ( $-2 \mathrm{~kb}$ to $+1 \mathrm{~kb}$ around the $N R 2 B$ transcription start site) (Fig. 6A). We show that long-term treatment with 3 or $10 \mu \mathrm{M}$ of imipramine relatively increased H3K9 (Fig. 6B) and H3K27 (Fig. 6C) acetylation in regions proximal to the transcriptioninitiation site (primer regions 7 to 9).

\section{Discussion}

Imipramine, a drug used to treat major depression, is known to upregulate NMDA receptor expression in patients with major depression (Haenisch and Bönisch, 2011). Hence, the goal of this study was to detail the effects of imipramine on NMDA receptor expression and to clarify the mechanism by which these effects occur. We found that long-term, but not acute, imipramine treatment increased $\mathrm{Ca}^{2+}$ influx mediated by NMDA receptors. Furthermore, long-term imipramine treatment increased the expression of NR2B, an NMDA receptor subunit. HDAC activity and expression were decreased in long-term imipramine-treated neurons, which in turn led to increases in $\mathrm{H} 3 \mathrm{~K} 9 \mathrm{ac}$ and $\mathrm{H} 3 \mathrm{~K} 27 \mathrm{ac}$ at the global level and in the chromatin bearing the $N R 2 B$ promoter. Taken together, these findings suggest that the duration of imipramine treatment determines its effects on NMDA receptors, and that imipramine directly enhances NR2B expression by modulating HDAC activity via epigenetic regulation.

Here we show that imipramine has bidirectional effects on NMDA receptors depending on the duration of treatment (acute versus long-term). A recent study has 
shown that acute imipramine treatment inhibits NMDA receptor function in vitro (Takebayashi et al., 2000). In line with this previous report, our results showed an inhibitory effect of acute imipramine treatment on NMDA-induced $\mathrm{Ca}^{2+}$ influx. However, the mechanism responsible for this acute effect remains unknown. One possibility is that imipramine works as a channel blocker, as the $\mathrm{Ca}^{2+}$ response induced by acute imipramine treatment returned to normal once imipramine was washed out of the cultures. Some studies suggest that imipramine has an action site on the NMDA receptor complex, similar to the $\mathrm{Zn}^{+2}$-recognition site (Reynolds and Miller, 1988). Nevertheless, because these acute effects develop and resolve in minutes, it is difficult to explain why imipramine needs $2-6$ weeks to exert its clinical effects.

In the present study, we demonstrated that NMDA-induced increases in $\left[\mathrm{Ca}^{2+}\right]_{\mathrm{i}}$ significantly rise in primary cultured neocortical neurons following long-term imipramine treatment. Since acute imipramine treatment led to an inhibitory effect on $\mathrm{Ca}^{2+}$ influx via direct binding to the active site, the increased influx due to long-term imipramine treatment must involve other mechanisms, such as epigenetic regulation, which is more effective than inhibition via receptor binding. On the other hand, mounting evidence, including cell loss in the subgenual prefrontal cortex and atrophy in the dorsolateral and orbitofrontal prefrontal cortex (Belmaker and Agam, 2008; Rajkowska, 2000), has suggested that there is a dysregulation of neurogenesis in major depression. Since NMDA receptors are central to the mechanisms of neurogenesis, and calcium influx through activated NMDA receptors leads to synaptic plasticity, differentiation, gene regulation, and cell survival (Pittenger et al., 2007), it is likely that long-term imipramine treatment ameliorates neuronal cell injury in major depressive disorder by enhancing NMDA receptor function. 
We found that long-term imipramine treatment upregulated NR2B expression in primary cultured neocortical neurons. The majority of NMDA receptors are expressed as heteromeric complexes composed of two NR1 and two NR2 subunits, which can be NR2A or NR2B (Flores-Soto et al., 2012; Loftis and Janowsky, 2003). Since NR1 subunits are normally expressed in large excess and rapidly degrade when unassembled with NR2 subunits (Feyissa et al., 2009; Huh and Wenthold, 1999), it is highly likely that the NR2 subunits play the most important part in controlling the total number of functional NMDA receptors, which can explain the increase in NMDA receptor function following long-term imipramine treatment. This in vitro finding is in contrast to a previous in vivo finding by Boyer et al. that showed longterm administration of imipramine downregulated NR2B expression in the cortex, hippocampal CA1-4, and amygdala in mouse via unknown molecular mechanisms (Boyer et al, 1998). This discrepancy may be due to differences in dosages, as our final concentration of imipramine was higher than that used by Boyer. Other possibilities are that the effects of imipramine vary between brain regions, and that there are significant differences between in vivo and in vitro studies. Thus, it will be necessary to investigate whether imipramine recovers NR2B expression using a mouse model of depression.

In our study, long-term imipramine treatment decreased HDAC activity and expression of HDAC3 and HDAC4 in primary cultured neocortical neurons. Previous in vivo studies have demonstrated that hippocampal HDAC5 expression was downregulated by long-term imipramine, which increased histone acetylation of the $B D N F$ (brain-derived neurotrophic factor) promoter (Tsankova et al., 2006). Further, overexpression of HDAC5 blocks imipramine's ability to reverse depression-like behaviours in mice (Tsankova et al., 2006). Peripheral leukocyte HDAC5 expression 
was significantly higher in depressive patients than in controls and was reduced to baseline by paroxetine, a selective serotonin reuptake inhibitor (Iga et al., 2007). We did not observe a decrease in HDAC5 expression following long-term imipramine treatment, which can be explained by our use of non-stressed cortical neurons compared to the hippocampal neurons derived from stressed mice used in Tsankova et al's study. However, our results suggest that imipramine can contribute to the regulation of target genes, such as $B D N F$ and $N R 2 B$, by regulating histone acetylation. It has also been reported that expression of HDAC2/3/5 can increase in the mouse brain following treatment with antidepressants, such as sodium valproate and lithium chloride, and that this effect can differ between brain regions (Ookubo et al., 2013). These discrepancies suggest that imipramine's effects on HDACs may depend on the type of study (in vivo or in vitro), material studied (cultured neuron or brain tissue), brain region, and the antidepressant tested.

Our data showed that long-term imipramine enhanced global H3K9ac and $\mathrm{H} 3 \mathrm{~K} 27 \mathrm{ac}$ in neocortical neurons in vitro, an effect which may be explained by the concomitant decrease in HDAC activity and expression. The effects on global H3ac suggest that long-term imipramine can regulate the expression of genes relating to major depression by enhancing local histone acetylation in target gene promoters. A previous study has suggested that chronic imipramine treatment can enhance $B D N F$ expression (Tsankova et al., 2006). Our results revealed that local H3K9ac and $\mathrm{H} 3 \mathrm{~K} 27 \mathrm{ac}$ in the chromatin region of the $N R 2 B$ promoter are also increased. These results suggest that epigenetic regulation may be a new mechanism of action for imipramine in the treatment of depression.

Our study was designed as an in vitro study, using 'normal' neocortical neurons, so we are limited in our ability to extrapolate beyond our findings to consider in vivo 
conditions and depressive patients. We suggest that future research should investigate the effects of imipramine on depressive patients. Furthermore, to understand the role of NMDA receptors in neuroplasticity and neurogenesis, we suggest investigating the effects of imipramine on neural stem cells.

\section{Conclusion}

Our study demonstrated that one of the therapeutic mechanisms of imipramine might be the upregulation of NR2B receptor activity through increased histone acetylation. Since chemical screening is widely performed in light of epigenetic findings (Plazas-Mayorca and Vrana, 2011; Campbell and Tuminno, 2014), our findings may contribute to the development of new treatments for mental disorders. 


\section{Acknowledgments}

This research was supported by grants for Scientific Research B (26293245 to T Kubota), Scientific Research C (23591491 to T Hirasawa) and Exploratory Research ( 25670473 to T Kubota) from rom JSPS KAKENHI, Japan; and by a grant for Core Research for Evolutional Science and Technology (CREST) from the Japan Science and Technology Agency (JST) ('Development of Fundamental Technologies for Diagnosis and Therapy Based upon Epigenome Analysis' to T Hirasawa).We thank for the valuable discussion and comment (T Kubota, K Moriishi and S Koizumi), technical advice (H Kasai and K Mochizuki) and technical support to C Obata. We would like to thank Editage (www.editage.jp) for English language editing.

\section{References}

Attucci, S., Carla, V., Mannaioni, G., Moroni, F., 2001. Activation of type 5 metabotropic glutamate receptors enhances NMDA responses in mice cortical wedges. Br. J. Pharmacol. 132, 799-806. doi: 10.1038/sj.bjp.0703904

Awad, H., Hubert, G.W., Smith, Y., Levey, A.I., Conn, P.J., 2000. Activation of metabotropic glutamate receptor 5 has direct excitatory effects and potentiates NMDA receptor currents in neurons of the subthalamic nucleus. J. Neurosci. 20, 7871-7879. doi: information not provided

Belmaker, R.H., Agam, G., 2008. Major depressive disorder. New Engl. J. Med. 358, 55-68. doi: 10.1056/NEJMra073096

Beneyto, M., Kristiansen, L.V., Oni-Orisan, A., McCullumsmith, R.E., MeadorWoodruff, J.H., 2007. Abnormal glutamate receptor expression in the medial temporal lobe in schizophrenia and mood disorders. Neuropsychopharmacol. 32, 1888-1902. doi: 10.1038/sj.npp.1301312 
Boyer, P.A., Skolnick, P., Fossom, L.H., 1998. Chronic administration of imipramine and citalopram alters the expression of NMDA receptor subunit mRNAs in mouse brain. J. Mol. Neurosci. 10, 219-233. doi: 10.1007/BF02761776

Broide, R.S., Redwine, J.M., Aftahi, N., Young, W., Bloom, F.E., Winrow, C.J., 2007. Distribution of histone deacetylases 1-11 in the rat brain. J. Mol. Neurosci. 31, 4758. doi: 10.1385/JMN/31:01:47

Campbell, R.M., Tummino, P.J., 2014. Cancer epigenetics drug discovery and development: the challenge of hitting the mark. J. Clin. Invest. 124, 64-69. doi: 10.1172/JCI71605

Cotter, D., Mackay. D., Chana. G., Beasley. C., Landau. S., Everall. I.P., 2002. Reduced neuronal size and glial cell density in area 9 of the dorsolateral prefrontal cortex in subjects with major depressive disorder. Cereb. Cortex 12, 386-394. doi: 10.1093/cercor/12.4.386

De Ruijter, A.J., Van Gennip, A.H., Caron, H.N., Kemp, S., Van Kuilenburg, A.B., 2003. Histone deacetylases (HDACs): characterization of the classical HDAC family. Biochem. J. 370, 737-749. doi: 10.1042/BJ20021321

Feyissa, A.M., Chandran, A., Stockmeier, C.A., Karolewicz, B., 2009. Reduced levels of NR2A and NR2B subunits of NMDA receptor and PSD-95 in the prefrontal cortex in major depression. Prog. Neuro-Psychoph. 33, 70-75. doi: 10.1016/j.pnpbp.2008.10.005

Flores-Soto, M.E., Chaparro-Huerta, V., Escoto-Delgadillo, M., Vazquez-Valls, E., González-Castãeda, R.E., Beas-Zarate, C., 2012. Structure and function of NMDA-type glutamate receptor subunits. Neurologia 27, 301-310. doi: 10.1016/j.nrleng.2011.10.003 
Furumai, R., Komatsu, Y., Nishino, N., Khochbin, S., Yoshida, M., Horinouchi, S., 2001. Potent histone deacetylase inhibitors built from trichostatin A and cyclic tetrapeptide antibiotics including trapoxin. PNAS 98, 87-92. doi: 10.1073/pnas.98.1.87

Haenisch, B., Bönisch, H., 2011. Depression and antidepressant: insights from knockout of dopamine, serotonin or noradrenaline re-uptake transporters. Pharmacol. Ther. 129, 352-368. doi: 10.1016/j.pharmthera.2010.12.002

Hardingham, G.E., Bading, H., 2003. The Yin and Yang of NMDA receptor signaling. Trens. Neurosci. 26, 81-89. doi: 10.1016/S0166-2236(02)00040-1

Hirasawa, T., Nakamura, K., Mizushima, A., Morita, M., Ezawa, I., Miyakawa, H., Kudo, Y., 2000. Adverse effects of an active fragment of parathyroid hormone on rat hippocampal organotypic cultures. Br. J. Pharmacol. 129, 21-28. doi: 10.1038/sj.bjp.0702949

Honma, K., Mochizuki, K., Goda, T., 2013. Induction by fructose force-feeding of histone $\mathrm{H} 3$ and $\mathrm{H} 4$ acetylation at their lysine residues around the Slc2a5 Gene and its expression in mice. Biosci. Biotechnol. Biochem. 77, 2188-2191. doi: 10.1271/bbb.130300

Huh, K.H., Wenthold, R.J., 1999. Turnover analysis of glutamate receptors identifies rapidly degraded pool of the $\mathrm{N}$-methyl-D-aspartate receptor subunit, NR1, in cultured cerebellar granule cells. J. Biol. Chem. 274, 151-157. doi: $10.1074 / \mathrm{jbc} .274 .1 .151$

Iga, J., Ueno, S., Yamauchi, K., Numata, S., Kinuchi, S., Tayoshi-Shibuya, S., Song, H., Ohmori, T., 2007. Altered HDAC5 and CREB mRNA expressions in the peripheral leukocytes of major depression. Prog. Neuro. Psychoph. 31, 628-632. doi: 10.1016/j.pnpbp.2006.12.014 
Jenuwein, T., Allis, C.D., 2001. Translating the histone code. Science 293, 1074-1080. doi: $10.1126 /$ science. 1063127

Joshi, D.C., Singh, M., Krishnamurthy, K., Joshi, P.G., Joshi, N.B., 2011. AMPA induced $\mathrm{Ca}^{2+}$ influx in motor neurons occurs through voltage gated $\mathrm{Ca}^{2+}$ channel and $\mathrm{Ca}^{2+}$ permeable AMPA receptor. Neurochem. Int. 59, 913-921. doi: 10.1016/j.neuint.2011.06.023

Karpova, A., Mikhaylova, M., Bera, S., Bär, J., Reddy, P.P., Behnisch, T., Rankovic, V., Spilker, C., Bethge, P., Sahin, J., Kaushik, R., Zuschratter, W., Kähne, T., Naumann, M., Gundelfinger, E.D., Kreutz, M.R., 2013. Encoding and transducing the synaptic or extrasynaptic origin of NMDA receptor signals to the nucleus. Cell 152, 1119-1133. doi: 10.1016/j.cell.2013.02.002

Krishnan, V., Nestler, E.J., 2008. The molecular neurobiology of depression. Nature 455, 894-902. doi: 10.1038/nature07455

Kouzarides, T., 2007. Chromatin modifications and their function. Cell 128, 693-705. doi: 10.1016/j.cell.2007.02.005

Lee, D.Y., Hayes, J.J., Pruss, D., Wolffe, A.P., 1993. A positive role for histone acetylation in transcription factor access to nucleosomal DNA. Cell 72, 73-84. doi: 10.1016/j.cell.2007.02.005

Li, F., Tsien, J.Z., 2009. Memory and the NMDA receptors. N. Engl. J. Med. 361, 302-303. doi: 10.1056/NEJMcibr0902052

Loftis, J.M., Janowsky, A., 2003. The $N$-methyl-D-aspartate receptor subunit NR2B: localization, functional properties, regulation, and clinical implications. Pharmacol. Ther. 97, 55-85. doi: 10.1016/S0163-7258(02)00302-9

Miyakawa, H., Ross, W.N., Jaffe, D., Callaway, J.C., Lasser-Ross, N., Lisman, J.E., Johnston, D., 1992. Synaptically activated increases in $\mathrm{Ca}^{2+}$ concentration in 
hippocampal CA1 pyramidal cells are primarily due to voltage-gated $\mathrm{Ca} 2+$ channels. Neurons 9, 1167-1173. doi: 10.1016/0896-6273(92)90074-N

Nowak, G., Pomierny-Chamioło, L., Siwek, A., Niedzielska, E., Pomierny, B., Pałucha-Poniewiera, A., Pilc, A., 2014. Prolonged administration of antidepressant drugs leads to increased binding of $\left[{ }^{3} \mathrm{H}\right] \mathrm{MPEP}$ to mGlu5 receptors. Neuropharmacology 84, 46-51. doi: 10.1016/j.neuropharm.2014.04.016

Nudmamud-Thanoi, S., Reynolds, G.P., 2004. The NR1 subunit of the glutamate/NMDA receptor in the superior temporal cortex in schizophrenia and affective disorders. Neurosci. Lett. 372, 173-177. doi: 10.1016/j.neulet.2004.09.035

Ookubo, M., Kanai, H., Aoki, H., Yamada, N., 2013. Antidepressants and mood stabilizers effects on histone deacetylase expression in C57BL/6 mice: brain region specific changes. J. Psychiat. Res. 47, 1204-1214. doi: 10.1016/j.jpsychires.2013.05.028

Pittenger, C., Sanacora, G., Krystal, J.H., 2007. The NMDA receptor as a therapeutic target in major depressive disorder. CNS Neurol. Disord. Drug Targets 6, 101-115. doi: $10.2174 / 187152707780363267$

Plazas-Mayorca, M.D., Vrana K.E., 2011. Proteomic investigation of epigenetics in neuropsychiatric disorders: A missing link between genetics and behavior? J. Proteome Res. 10, 58-65. doi: 10.1021/pr100463y

Qiang, M., Denny, A., Chen, J., Ticku, M.K., Yan, B., Henderson, G., 2010. The site specific demethylation in the 5'-regulatory area of NMDA receptor $2 \mathrm{~B}$ subunit gene associated with CIE-induced up-regulation of transcription. PLoS One 5(1), e8798. doi: 10.1371/journal.pone.0008798 
Rajkowska, G., Miguel-Hidalgo, J.J, Wei, J., Dilley, G, Pittman, S.D., Meltzer, H.Y., Overholser, J.C., Roth, B.L., Stockmeier, C.A., 1999. Morphometric evidence for neuronal and glial prefrontal cell pathology in major depression. Biol. Psychiat. 45, 1085-1098. doi: 10.1016/S0006-3223(99)00041-4

Rajkowska, G., 2000. Postmortem studies in mood disorders indicate altered numbers of neurons and glial cells. Biol. Psychiat. 48, 766-777. doi: 10.1016/S00063223(00)00950-1

Reynolds, I.J., Miller, R.J., 1988. Tricyclic antidepressants block N-methyl-Daspartate receptors: similarities to the action of zinc. Br. J. Pharmacol. 95, 95-102. doi: 10.1111/j.1476-5381.1988.tb16552.x

Schildkraut, J.J., 1965. The catecholamine hypothesis of affective disorders: a review of supporting evidence. Am. J. Psychiatry 122, 509-522. doi: 10.1016/S00142999(99)00330-1

Scolnick, P., 1996. Antidepressants for the new millennium. Eur. J. Pharmacol. 375, 31-40. doi: 10.1016/S0014-2999(99)00330-1

Takai, H., Katayama, K., Uetsuka, K., Nakayama, H., Doi, K., 2003. Distribution of $\mathrm{N}$-methyl-D-aspartate receptor in the developing rat brain. Exp. Mol. Pathol. 75, 89-94. doi: 10.1016/S0014-4800(03)00030-3

Takebayashi, M., Kagaya, A., Inagaki, M., Kozuru, T., Jitsuiki, H., Kutura, K., Okamoto, Y., Yamawaki, S., 2000. Effects of antidepressants on $\gamma$-aminobutyric acid and $\mathrm{N}$-methyl- $D$-aspartate-induced intracellular $\mathrm{Ca}^{2+}$ concentration increases in primary cultured rat neocortical neurons. Neuropsychobiology 42, 120-126. doi: $10.1159 / 000026681$

Tsankova, N., Renthal, W., Kumar, A., Nestler, E.J., 2007. Epigenetic regulation in psychiatric disorders. Nat. Rev. Neurosci. 8, 355-367. doi:10.1038/nrn2132 
Tsankova, N., Berton, O., Renthal, W., Kumar, A., Neve, R., Nestler, E.J., 2006. Sustained hippocampal chromatin regulation in a mouse model of depression and antidepressant action. Nat. Neurosci. 9, 519-525. doi:10.1038/nn1659

Yoshida, M., Kijima, M., Akita, M., Beppu, T., 1990. Potent and specific inhibition of mammalian histone deacetylase both in vivo and in vitro by Trichostatin. A. J. Biol. Chem. 265, 17174-17179. doi: information not provided

Yoshida, M., Horinouchi, S., Beppu, T., 1995. Trichostatin A and trapoxin: novel chemical probes for the role of histone acetylation in chromatin structure and function. Bioessays 17, 424-430. doi: 10.1002/bies.950170510

Yuen, E.Y., Wei, J., Liu, W., Zhong, P., Li, X., Yan, Z., 2012. Repeated stress caused cognitive impairment by suppressing glutamate receptor expression and function in prefrontal cortex. Neuron 73, 962-977. doi: 10.1016/j.neuron.2011.12.033 


\section{Figure legends}

Fig. 1. Effect of acute (30 s) imipramine treatment on $N$-methyl-D-aspartate (NMDA)-induced $\mathrm{Ca}^{2+}$ influx in primary cultured neocortical neurons. (A) Calcium imaging of NMDA-induced $\mathrm{Ca}^{2+}$ influx. Imi; imipramine, NMDA; $30 \mathrm{~s}$ of $30 \mu \mathrm{M}$ NMDA (B) Percentage of calcium influx response to NMDA compared to control following acute imipramine. Data are based on three independent experiments. ${ }^{*} \mathrm{P}<$ 0.05 versus control; $* * \mathrm{P}<0.01$ versus control; $* * * \mathrm{P}<0.001$ versus control; \#P $<0.05$ versus $1 \mu \mathrm{M}$ imipramine; \#\# $<0.01$ versus $1 \mu \mathrm{M}$ imipramine; \#\#\# $<0.001$ versus 1 $\mu \mathrm{M}$ imipramine; $+\mathrm{P}<0.01$ versus $3 \mu \mathrm{M}$ imipramine; $++\mathrm{P}<0.001$ versus $3 \mu \mathrm{M}$ imipramine. Statistical analysis was performed using one-way ANOVA followed by Tukey's post hoc test.

Fig. 2. Effect of long-term (48 h) imipramine on $N$-methyl-D-aspartate (NMDA)induced $\mathrm{Ca}^{2+}$ influx in primary cultures of neocortical neurons. (A) Representative fluorometric traces of $\left[\mathrm{Ca}^{2+}\right]_{\mathrm{i}}$ increase after $30 \mathrm{~s}$ of $30 \mu \mathrm{M}$ NMDA, with and without $10 \mu \mathrm{M}$ imipramine. (B) NMDA-induced $\mathrm{Ca}^{2+}$ influx (NMDA response). (C) NMDA response with CNQX, a competitive AMPA receptor antagonist, and TTX, a voltagegated sodium channel blocker. Bars represent fold changes/untreated control. Data are presented as mean \pm S.E.M. $(\mathrm{n}=7)$. $* \mathrm{P}<0.05$ versus untreated control; $* * \mathrm{P}<0.01$ versus untreated controls. Statistical analysis was performed using one-way ANOVA followed by Tukey's post hoc test.

Fig. 3. Changes in $N$-methyl-D-aspartate (NMDA) receptor subunit protein expression following long-term imipramine in primary cultured neocortical neurons. 
(A) NR1 protein expression. (B) NR2A protein expression. (C) NR2B protein expression. Bars represent relative ratio of treated and untreated controls. Data are presented as means \pm S.E.M. and are based on six (NR1, NR2A) and eight (NR2B) experiments. Statistical analysis was performed using one-way ANOVA followed by Dunnett's T3 post hoc test. ${ }^{*} \mathrm{P}<0.05$ versus untreated control.

Fig. 4. Changes in histone deacetylases (HDACs) following long-term imipramine in primary cultured neocortical neurons. (A) Percentage of change in HDAC activity compared to control. (B) Change in HDAC1, HDAC2, HDAC3, HDAC4, HDAC5, and HDAC11 expression in Western blot and relative expression of these HDACs. Bars represent fold changes/untreated controls. Data are presented as means \pm S.E.M. $* \mathrm{P}<0.05$ versus untreated control; \#P $<0.001$ versus untreated controls. Statistical analysis was performed using one-way ANOVA followed by Tukey's or Dunnett's T3 post hoc test.

Fig. 5. Changes in histone acetylation following long-term imipramine in primary cultured neocortical neurons. (A) Change in acetylation of histone H3K9. (B) Changes in acetylation of histone H3K27. Values are presented as means \pm S.E.M. and represent fold changes over corresponding controls. $* \mathrm{P}<0.05$ versus control. Statistical analysis was performed using one-way ANOVA followed by Dunnett's T3 post hoc test.

Fig. 6. Changes in histone acetylation in upstream region of mouse $N R 2 B$ following long-term imipramine treatment in primary cultured neocortical neurons. (A) 
Location of PCR primers in upstream region of mouse $N R 2 B$ (primer sequences are shown in Table S1). (B) Fold changes in histone H3K9 acetylation. (C) Fold changes in histone H3K27 acetylation. Data are based on three independent experiments. Values are presented as means \pm S.E.M. and represent fold changes over corresponding controls. 
Nguyen A Nghia et al.

Imipramine effects to the NMDA receptors via epigenetic regulation

\section{Figure 1}

A

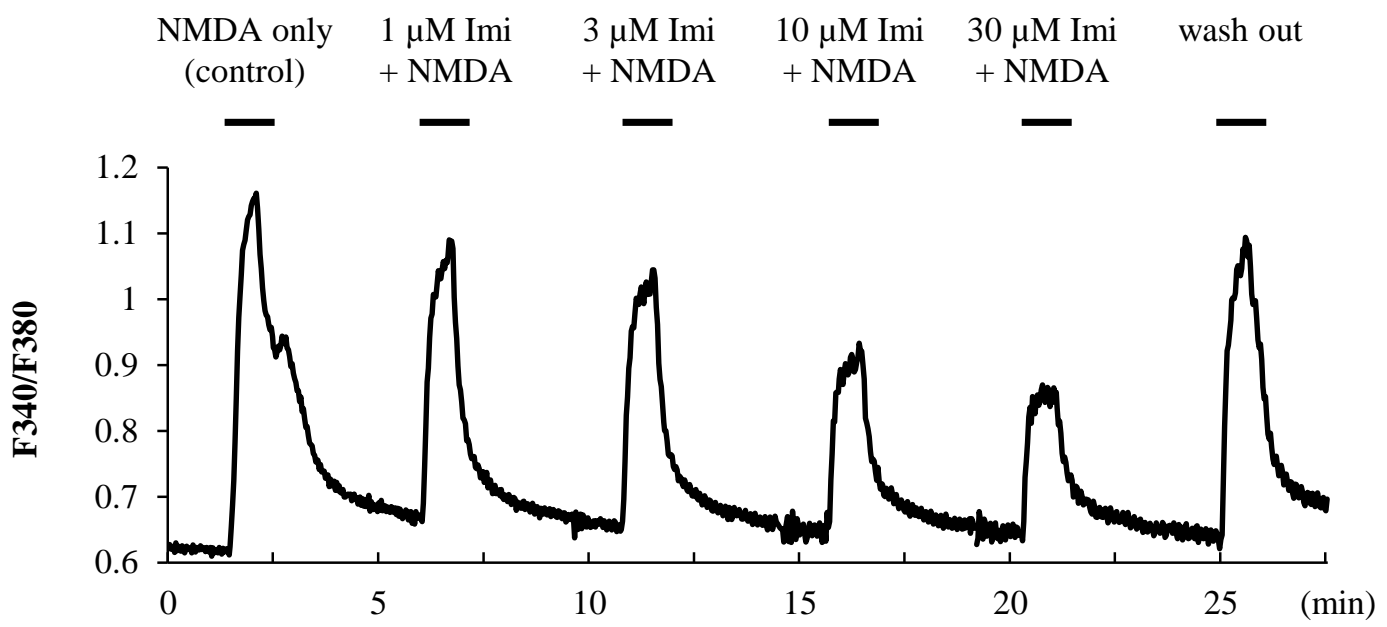

B

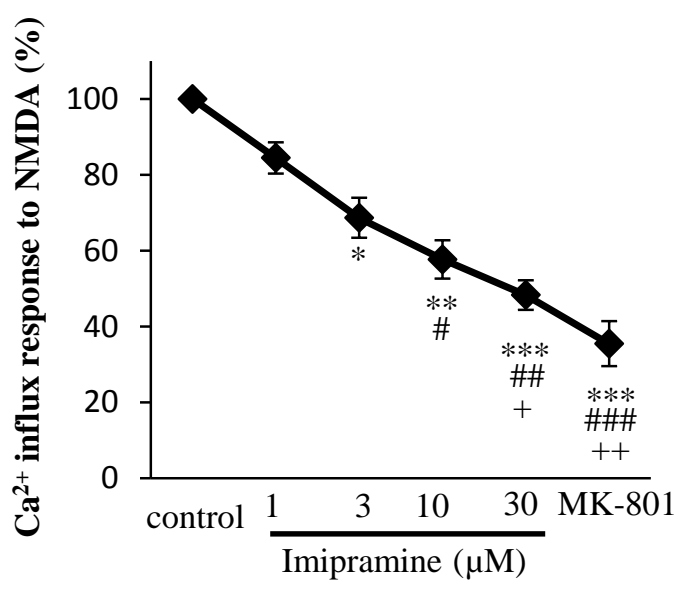




\section{Figure 2}

control

A

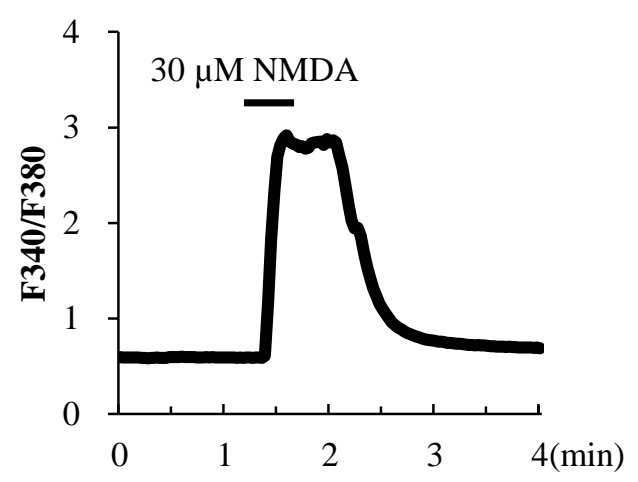

B

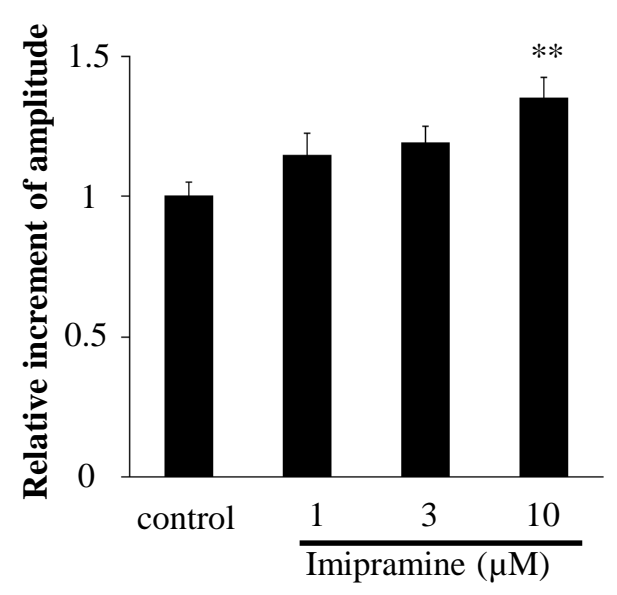

$10 \mu \mathrm{M}$ imipramine treatment $48 \mathrm{~h}$

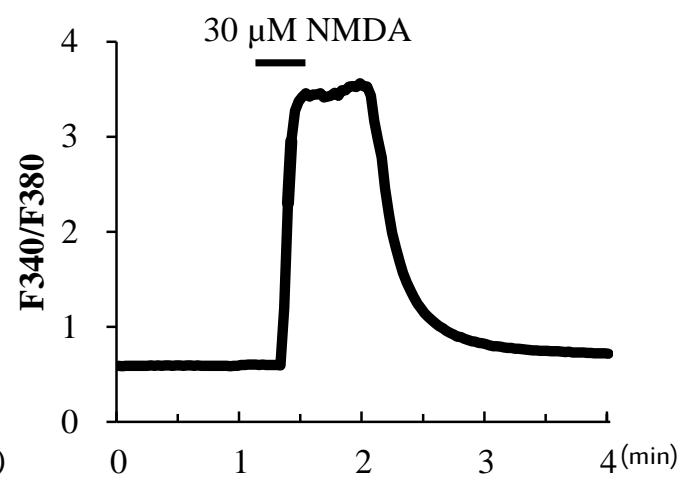

C

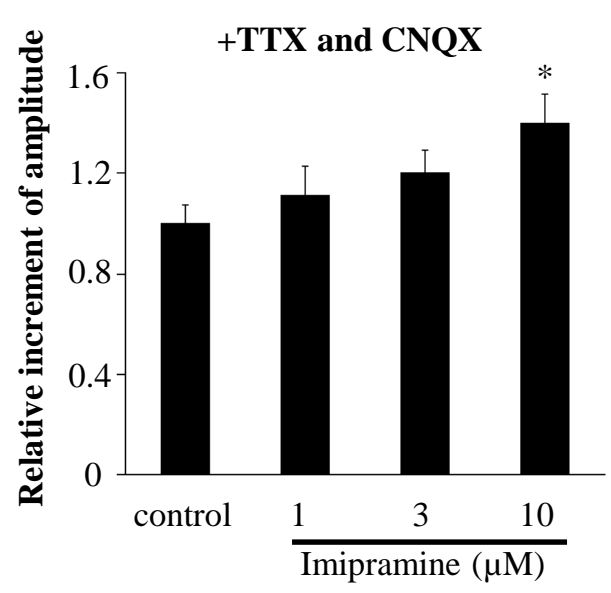




\section{Figure 3}

A
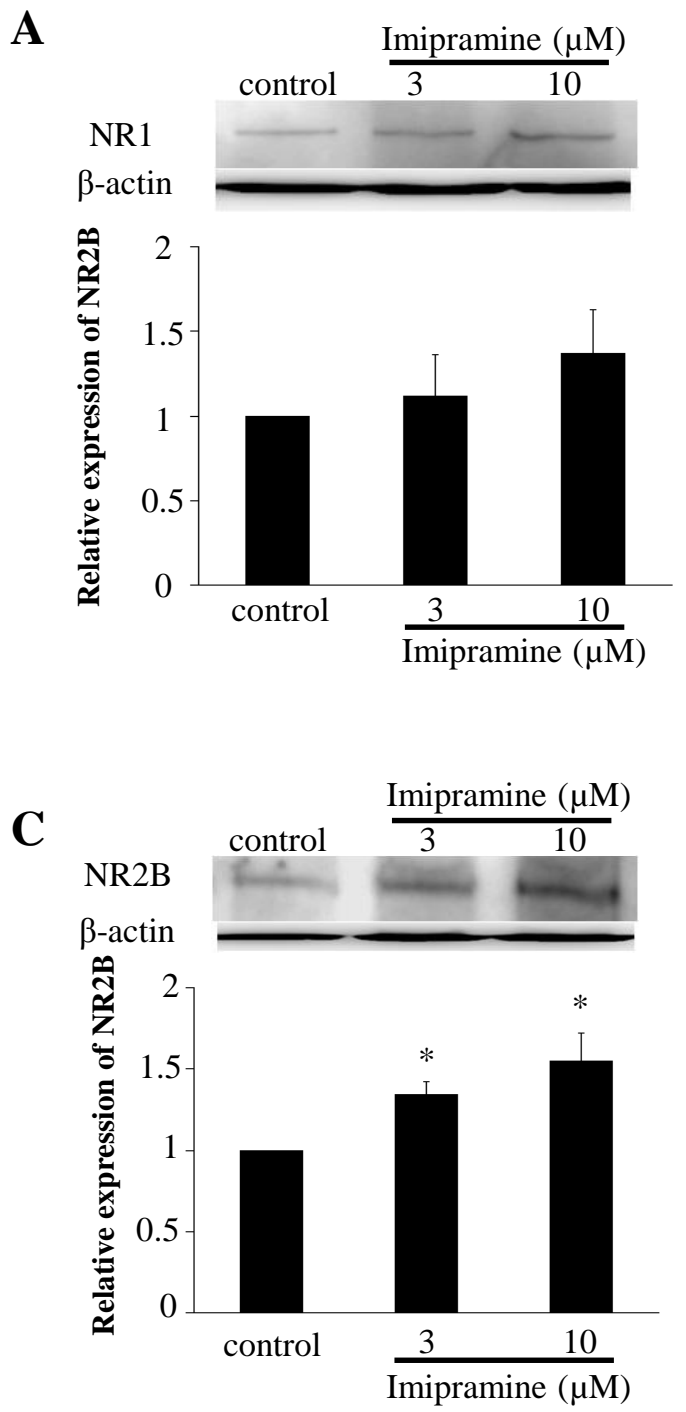

B

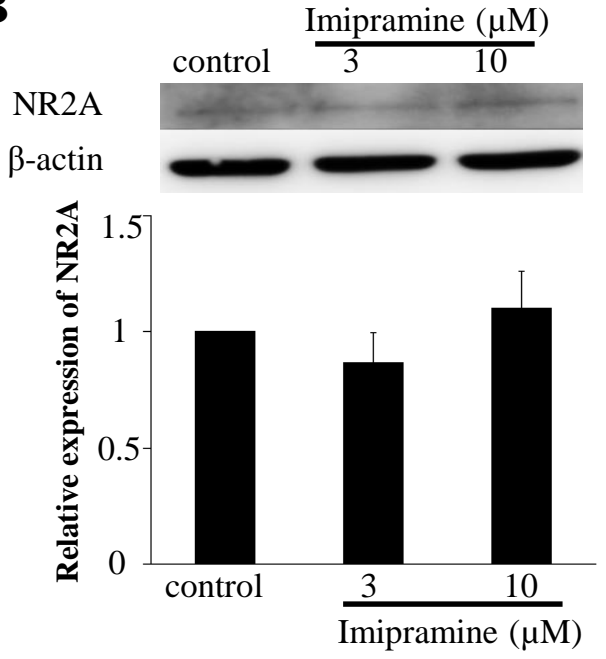




\section{Figure 4}

A

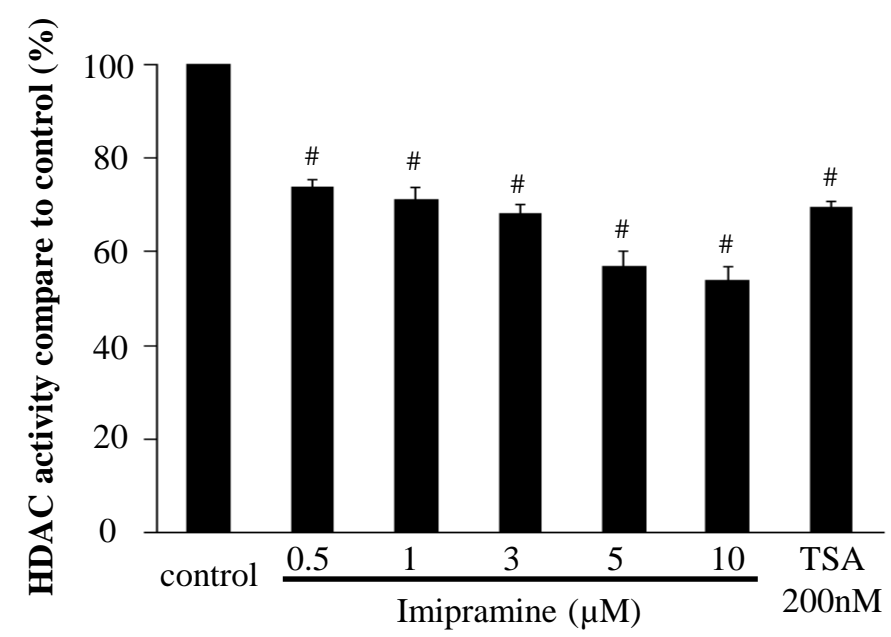

B

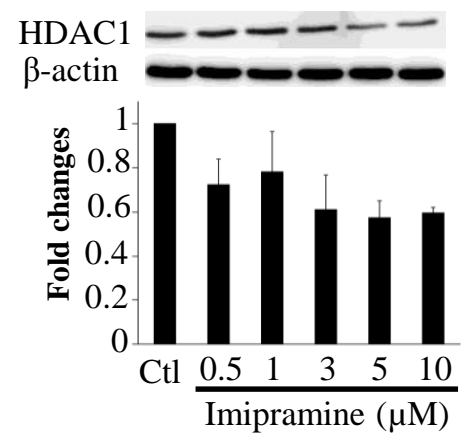

HDAC2 - - - - $\beta$-actin

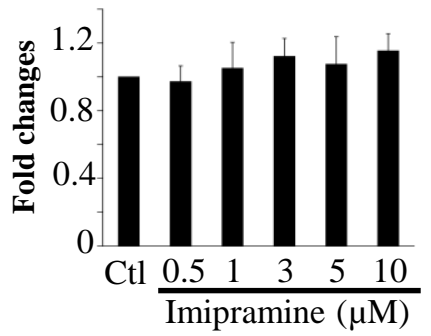

HDAC5

$\beta$-actin

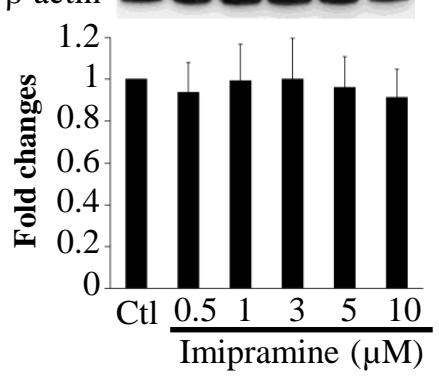

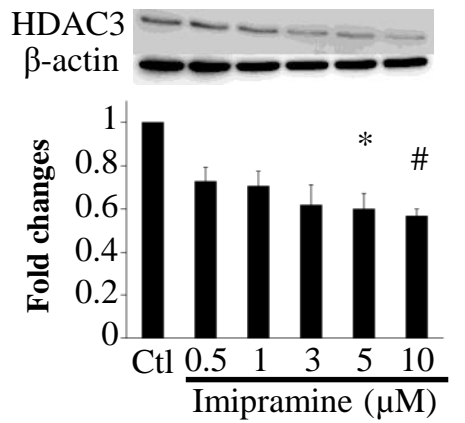

HDAC11

$\beta$-actin

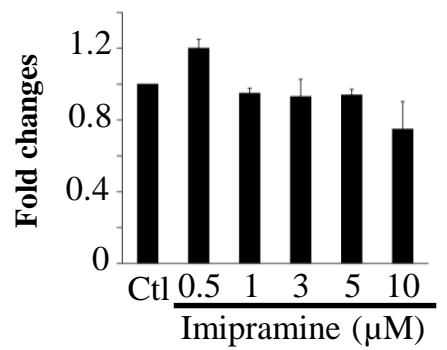




\section{Figure 5}

A

Imipramine $(\mu \mathrm{M})$

H3K9ac

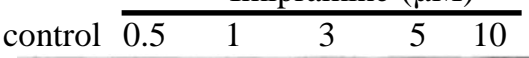

Global H3

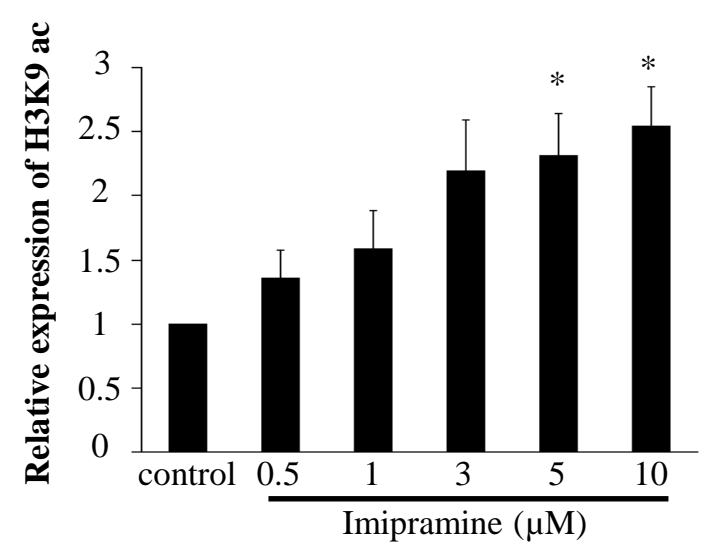

B

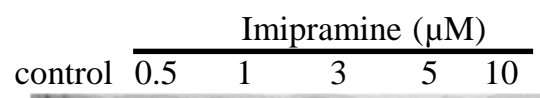

H3K27ac

Global H3

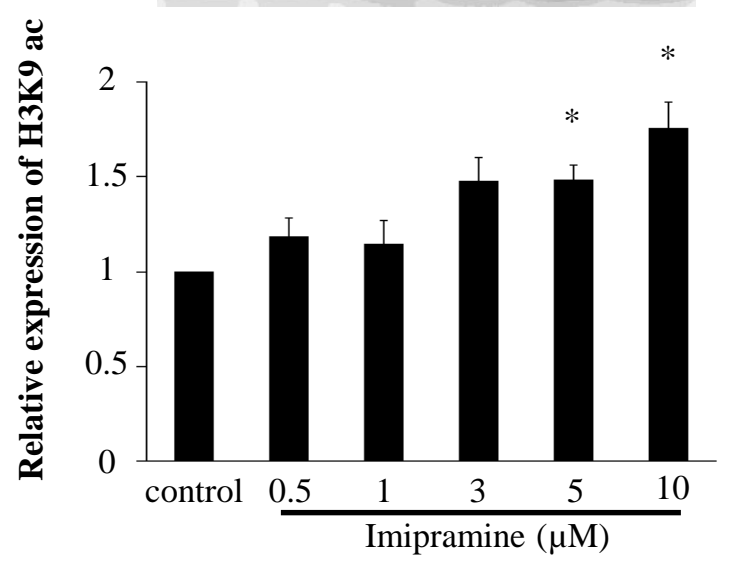




\section{Figure 6}

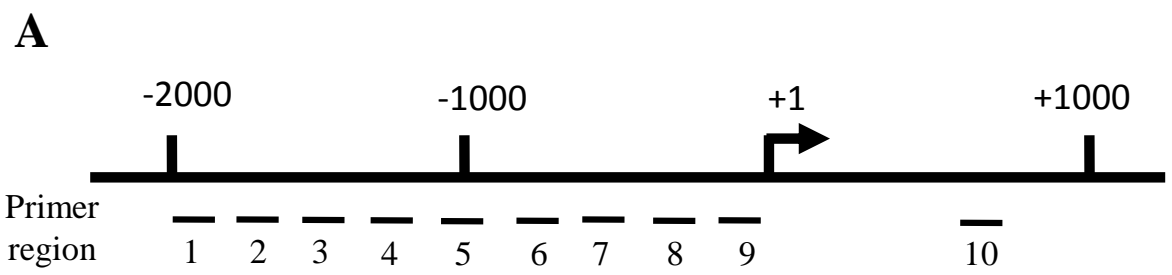

B
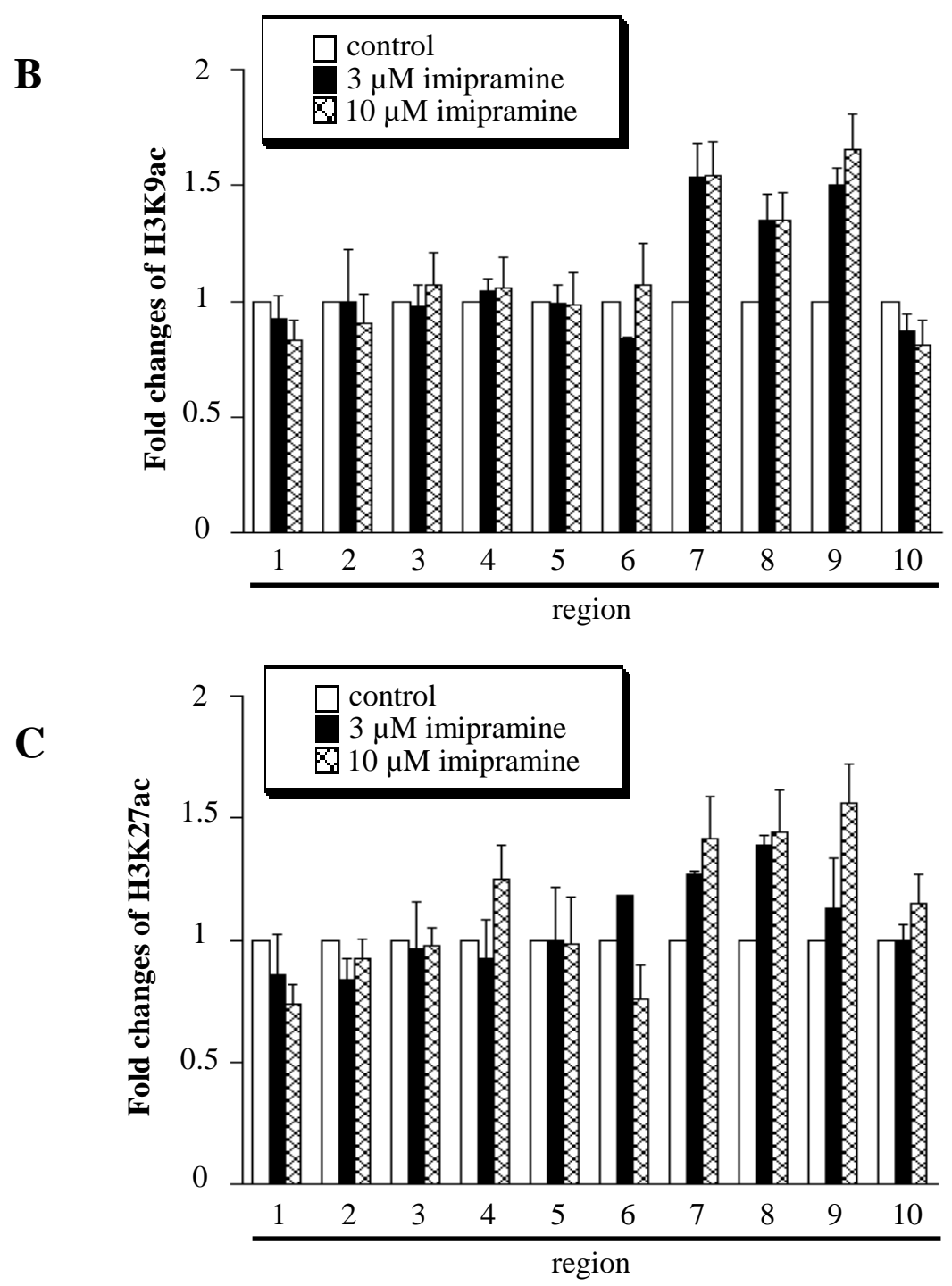